\title{
FAKTOR LINGKUNGAN FISIK RUMAH DAN KEJADIAN TUBERKULOSIS PARU DI WILAYAH PESISIR
}

\author{
HOUSE PHYSICAL CONDITION FACTORS AND INCIDENCE OF PULMONARY \\ TUBERCULOSIS IN COASTAL AREA
}

\author{
Maryati Agustina Tatangindatu, Melanthon Juneidi Umboh \\ Program Studi Keperawatan, Politeknik Negeri Nusa Utara \\ Email: mtatangindatu@gmail.com
}

\begin{abstract}
Abstrak: Tuberculosis (TB) merupakan penyakit infeksi bakteri menahun yang disebabkan oleh Mycobakterium Tuberculosis. TB merupakan salah satu dari sepuluh tertinggi penyebab kematian di seluruh dunia. Di Indonesia angka kematian akibat TB mencapai 140.000 orang per tahun. Di Kabupaten kepulauan Sangihe Tuberkulosis Paru masih menjadi masalah kesehatan. Pada tahun 2018 jumlah kasus TB di Wilayah Puskesmas Manenete berjumlah 21 kasus dan terjadi peningkatan kasus pada tahun 2019 menjadi 44 kasus. Tujuan dari penelitian ini untuk mengetahui hubungan antara faktor lingkungan fisik rumah dengan kejadian TB Paru di Wilayah Puskesmas Manente. Jenis penelitian ini merupakan penelitian survei analitik dengan pendekatan cross sectional. Hasil analisis bivariat menggunakan uji chi square menunjukkan variabel kepadatan hunian, ventilasi rumah serta jenis dinding rumah memiliki $\mathrm{P}$ value kurang dari $0.05(<0.05)$. Untuk variabel jenis lantai diperoleh nilai $\mathrm{P}$ value lebih dari 0.05 (>0.05). Berdasarkan hasil penelitian dapat disimpulkan bahwa terdapat hubungan antara kepadatan hunian, ventilasi rumah dan jenis dinding rumah dengan kejadian TB Paru serta tidak terdapat hubungan antara jenis lantai rumah dengan kejadia TB Paru di Wilayah Puskesmas Manente. Pemerintah dan instansi terkait perlu melakukan promosi kesehatan secara rutin terkait upaya pencegahan TB Paru serta mengedukasi masyarakat untuk dapat meningkatkan daya tahan tubuh dengan menerapkan pola hidup bersih dan sehat.
\end{abstract}

Kata Kunci: Tuberkulosis, Faktor risiko, Kondisi fisik rumah

Abstract: Tuberculosis (TB) is a chronic bacterial infection caused by Mycobacterium tuberculosis. TB is one of the top ten causes of death worldwide. Death caused by TB amount 140,000 people in a year. In Sangihe District, Pulmonary Tuberculosis was a health problem. In 2018 the number of TB cases in Manente Health Center area were 21 cases and increased in 201944 cases. The purpose of this study was to determine the relationship between house physical condition factors with the incidence of pulmonary tuberculosis in the Manente Health Center area. Those reseach were analytic survey research with a cross sectional approach. The results of bivariate analysis used the Chi Square Test showed that the variables of house density, house ventilation and type of house walls had a $P$ value of less than 0.05 (<0.05). For the floor type variable, the P value was more than 0.05 (> 0.05). Based on the results the reaseach concluded that those was a relationship between house density, house ventilation and type of house wall with the incidence of Pulmonary Tuberculosis and there was no relationship between the type of floor of the house and the incidence of Pulmonary Tuberculosis in Manente Health Center area. The government and related officer need to carry out regular health promotions about how to prevent Pulmonary Tuberculosis and educate the public able to increase endurance by implementing a clean and healthy lifestyle.

Keywords: Tuberculosis, Risk Factor, House Physical Conditions

\section{PENDAHULUAN}

Tuberculosis (TB) adalah suatu penyakit

yang disebabkan oleh infeksi bakteri

Mycobacterium tuberculosis. Salah satu tanda dari penyakit TB yakni terbentuknya granuloma pada jarringan tang terinfeksi (Asih, 2004). TB merupakan salah satu dari sepuluh tertinggi penyebab kematian di seluruh dunia. Sekitar dua milyar orang atau 1/3 penduduk dunia diperkirakan terkena TB laten.Penderita tuberkulosis di kawasan Asia terus bertambah. Wilayah Asia merupakan wilayah dengan penyebaran kasus tuberkulosis (TB) 
tertinggi di dunia. sebelas negara dengan jumlah kasus TB tertinggi berada di wilayah Asia yakni Bangladesh, China, India, Indonesia dan Pakistan. Sebagian besar kasus TB di Asia termasuk pada kelompok usia produktif (Kompas, 2007). Angka kematian akibat TB di Indonesia mencpai 140.000 orang per tahun atau 8 persen dari korban meninggal di seluruh dunia. terdapat lebih dari 500.000 kasus baru TB setiap tahunnya dan 75 persen diantaranya termasuk pada kelompok usia produktif.

Di Kabupaten kepulauan Sangihe Tuberkulosis Paru masih menjadi masalah kesehatan, tercatat pada tahun 2018 jumlah penemuan kasus Tb paru yang diperiksa secara klinis sebanyak 2.689 kasus dan yang BTA (+) sebanyak 225 kasus dari jumlah perkiraan kasus baru yaitu 265 kasus. Sedangkan case detection rate (CDR) untuk tahun 2018 sebesar 114,89\%. Tahun 2019 kasus Tb paru BTA (+) sebesar 202. Diantara 17 puskesmas yang ada dikabupaten kepulauan sangihe, kasus TB Paru di Puskesmas Manente sebanyak 21 kasus ditahun 2018 dan terjadi peningkatan pada tahun 2019 menjadi 44 kasus dengan perincian laki-laki sebanyak 28 kasus dan perempuan 16 kasus, kelurahan wilayah manente terdiri dari 8 kelurahan yaitu, Soataloara, sawang bendar, Apengsembeka, Bungalawang, Santiago, Manente, dan Mahena. (Anonim 2020).

Beberapa penelitian yang telah dilakukan menemukan beberapa faktor yang menjadi penyebab terjadinya Tb paru, ratnasari (2005) meneliti tentang faktor risiko $\mathrm{Tb}$ paru dibeberapa unit pelayanan kesehatan kota semarang menemukan bahwa kepadatan hunian berhubungan dengan kejadian $\mathrm{Tb}$ paru dimana odd Ratio (OR) sebesar 2,4 dengan 95\% Confidence Interval (CI) : 1,09-5,47, selanjutnya pencahayaan dimana OR sebesar 2,7 dengan 95\% CI : 1,18-5,99 dan luas ventilasi dimana OR : 2,3 dengan 95\% CI : 1055.00 .

\section{METODE PENELITIAN}

Jenis penelitian ini adalah penelitian survei yang bersifat analitik dengan menggunakan pendekatan cross sectional. Analisis bivariatdengan uji chi squaremenggunakan komputerisasi.

\section{HASIL DAN PEMBAHASAN}

Berdasarkan tabel 1, dapat dilihat bahwa dari 40 responden dalam penelitian ini, $19(47.5 \%)$ responden merupakan warga masyarakat yang telah didiagnosa TB Paru oleh petugas medis sedangkan 21 (52.2\%) responden lainnya tidak pernah didiagnosa mengidap TB Paru oleh perugas medis. Pada tabel tersebut dapat pula diketahui bahwa sebagian besar responden pada penelitian ini termasuk pada kategori usia lebih dari 55 tahun yaitu sebanyak 17 (42.5\%) responden. Dilihat berdasarkan pendidikan terakhir, maka sebagian besar responden memiliki pendidikan terakhir SMA dengan jumah $17(42.5 \%)$ responden. Dalam penelitian ini, reponden terbanyak merupakan ibu rumah tangga dengan jumlah $12(30 \%)$ responden.

Tabel 1. Distribusi Responden Berdaarkan Karakteristik

\begin{tabular}{lll}
\hline Karakteristik Responden & $\mathrm{n}$ & $\%$ \\
\hline Kejadian TB & & \\
TB Paru & 19 & 47.5 \\
Tidak Tb & 21 & 52.5 \\
\hline Kelompok Umur (Tahun) & & \\
15-24 & 8 & 20 \\
25-54 & 15 & 37.5 \\
$>55$ & 17 & 42.5 \\
\hline Pendidikan Terakhir & & \\
SD & 0 & 0 \\
SMP & 8 & 20 \\
SMA & 17 & 42.5 \\
Pendidikan Tinggi & 15 & 37.5 \\
\hline Pekerjaan & & \\
Buruh & 6 & 15 \\
IRT & 12 & 30 \\
Nelayan & 1 & 2.5 \\
Pelajar & 3 & 7.5 \\
Pensiunan & 3 & 7.5 \\
Petani & 8 & 20 \\
Swasta & 4 & 10 \\
Tidak Bekerja & 3 & 7.5 \\
\hline
\end{tabular}


Berdasarkan tabel 2 dapat dilihat bahwa $47.5 \%$ responden memiliki tingkat kepadatan hunian yang tidak memenuhi syarat sedangkan $52.5 \%$ responden memiliki tingkat kepadatan hunian yang memenuhi.

Tabel 2. Hubungan Faktor Lingkungan Fisik Rumah Dengan Kejadian TB Paru

\begin{tabular}{|c|c|c|c|c|c|c|}
\hline \multirow{2}{*}{ Variabel } & \multirow{2}{*}{ Kategori } & \multicolumn{2}{|l|}{$\mathrm{TB}$} & \multicolumn{2}{|c|}{ Tidak TB } & \multirow{2}{*}{$P$} \\
\hline & & $\mathrm{n}$ & $\%$ & $\mathrm{n}$ & $\%$ & \\
\hline \multirow{3}{*}{$\begin{array}{l}\text { Kepada- } \\
\text { tan } \\
\text { Hunian }\end{array}$} & Tidak & 13 & 32.5 & 6 & 15 & \multirow{3}{*}{0.025} \\
\hline & $\begin{array}{l}\text { Memenuhi } \\
\text { Syarat }\end{array}$ & & & & & \\
\hline & $\begin{array}{l}\text { Memenuhi } \\
\text { syarat }\end{array}$ & 6 & 15 & 15 & 37.5 & \\
\hline \multirow{3}{*}{$\begin{array}{l}\text { Ventila- } \\
\text { si } \\
\text { Rumah }\end{array}$} & Tidak & & & & & \multirow{3}{*}{0.014} \\
\hline & $\begin{array}{l}\text { Memenuhi } \\
\text { Syarat }\end{array}$ & 14 & 35 & 7 & 17.5 & \\
\hline & $\begin{array}{l}\text { Memenuhi } \\
\text { syarat }\end{array}$ & 5 & 12.5 & 14 & 35 & \\
\hline \multirow{2}{*}{$\begin{array}{l}\text { Jenis } \\
\text { Lantai }\end{array}$} & $\begin{array}{l}\text { Tidak } \\
\text { Memenuhi } \\
\text { Syarat }\end{array}$ & 11 & 27.5 & 6 & 15 & \multirow{2}{*}{0.106} \\
\hline & $\begin{array}{l}\text { Memenuhi } \\
\text { syarat }\end{array}$ & 8 & 20 & 15 & 37.5 & \\
\hline \multirow[b]{2}{*}{$\begin{array}{l}\text { Jenis } \\
\text { Dinding }\end{array}$} & $\begin{array}{l}\text { Tidak } \\
\text { Memenuhi }\end{array}$ & 12 & 30 & 5 & 12.5 & \multirow[b]{2}{*}{0.024} \\
\hline & $\begin{array}{l}\text { Syarat } \\
\text { Memenuhi } \\
\text { syarat }\end{array}$ & 7 & 17.5 & 16 & 40 & \\
\hline
\end{tabular}

Hasil uji chi square menunjukkan bahwanilai $P$ value kurang dari nilai $\alpha 0,05$ yang artinya bahwa terdapat hubungan antara tingkat kepadatan hunian dengan kejadian TB Paru

Hunian yang terlalu padat dapat mempengaruhi penghuninya. luas rumah yang tidak sebanding dengan jumlah penghuni didalamnya akan membuat hunian tersebut overcrowded. Hal ini dapat menjadi risiko bila salah satu anggota keluarga terkena penyakit infeksi, terutama tuberkulosis akan mudah menular kepada anggota keluarga yang lain, dimana seorang penderita rata-rata dapat menularkan kepada 2-3 orang di dalam rumahnya.

Kepadatan menjadi pre-requisite untuk proses terjadinya penularan suatu penyakit. Hal tersebut disebabkan karena hunian yang padat akan mempermudah perpindahan penyakit khususnya penyakit yang dapat ditularkan melalui udara (Depkes, 1999). Hasil pada peneltian ini sejalan dengan penelitian yang dilakukan di Kabupaten Bangli yang menunjukkan adanya hubungan bermakna antara kepadatan hunian dengan kejadian TB Paru di Kabupaten Bangli Tahun 2012 (Lanus, Suyasa and Sujaya, 2012).

Dilihat berdasarkan faktor ventilasi rumah, sebanyak $52.5 \%$ responden memiliki ventilasi rumah yang tidak memenuhi persyaratan dan $47.5 \%$ responden telah memiliki ventilasi rumah yang memenuhi persyaratan. Berdasarkan analisis dengan chi square menunjukkan bahwa nilai $\mathrm{P}$ value 0.014 yang artinya bahwa terdapat hubungan antara ventilasi rumah dengan kejadian TB Paru.

Ventilasi mempunyai banyak fungsi diantaranya untuk menjaga agar aliran udara dalam rumah tersebut tetap sejuk. Artinya bahwa kesimbangan O2 dalam suatu hunian sangat diperlukan. Luas ventilasi yang kurang dapat menyebabkan kurangnya $\mathrm{O} 2$ dan meningkatkan kadar CO2 dalam hunian. Selain itu, luas ventilasi yang kurang akan meningkatkan kelembapan udara karena terjadi proses penguapan cairan dari kulit. Kelembapan ini menjadi media yang digunakan bakteri pathogen untuk berkembang seperti bakteri mycobacterium tuberculosis yang menyebabkan penyakit tuerkulosis (Notoatmodjo, 2010). Hasil pada penelitian ini serupa dengan hasil penelitian yang dilakukan oleh Anggraeni (2015) yang menunjukkan bahwa ada hubungan antara luas ventilasi dengan kejadian TB Paru di Wilayah Kerja Puskesmas Gondanglegi ( $p$ value $\leq 0,05$ ). Penelitian tersebut juga menunjukkan hasil $\mathrm{OR}=15,167$ yang artinya bahwa orang yang tinggal di rumah dengan luas ventilasi yang tidak memenuhi syarat kesehatan memiliki risiko 15 kali untuk menderita TB Paru dibandingkan dengan orang yang tinggal di rumah dengan luas ventilasi yang memenuhi syarat kesehatan.

Penelitian lain yang dilakukan oleh Pratama (2013) yang menunjukkan bahwa terdapat hubungan yang bermakna antara luas ventilasi dengan kejadian TB paru karena nilai $\mathrm{p}<0,005$. Ventilasi dan pencahayaan dapat menentukan kualitas udara dari pencemaran M. tuberculosis. Melalui ventilasi, udara dapat keluar membawa M. tuberculosis dan mati terkena sinar ultraviolet. Tidak cukupnya luas ventilasi 
juga dapat meningkatkan kelembaban ruangan. Kelembaban ruangan yang tinggi akan menjadi media yang baik untuk tumbuh dan berkembang biaknya bakteri-bakteri patogen termasuk M. tuberculosis (Setiyadi, 2019).

Berdasarkan faktor jenis lantai rumah, sebanyak $57.5 \%$ responden telah memiliki jenis lantai yang memenuhi persyaratan yaitu jenis lantai permanen sedangkan $42.5 \%$ responden memiliki jenis lantai yang tidak memenuhi syarat yaitu jenis lantai semi permanen. Berdasarkan hasil analisis dengan chi square diperoleh nilai $\mathrm{P}$ value lebih dari nilai $\alpha 0,05$ yang artinya tidak terdapat hubungan antara jenis lantai dengan kejadian TB Paru.

Menurut Keputusan Menteri Kesehatan Republik Indonesia No.829/Menkes/SK/VII/1999, jenis lantai yang memenuhi syarat kesehatan adalah yang kedap air dan mudah dibersihkan, seperti jenis lantai yang terbuat dari plester, ubin, semen, porselen atau keramik, sedangkan jenis lantai yang tidak memenuhi syarat kesehatan adalah tidak kedap air seperti jenis lantai tanah, papan, dan lontar. Hasil penelitian yang dilakukan menunjukkan bahwa tidak ada hubungan antara jenis lantai dengan kejadian TB Paru. Hasil penelitian ini sejalan dengan penelitian yang dilakukan Hamidah (2015) yang menunjukkan bahwa tidak ada hubungan yang signifikan antara jenis lantai dengan kejadian tuberkulosis paru. Penelitian lainnya yang dilakukan oleh Wulandari (2012) juga menunjukkan hasil yang serupa bahwa tidak ada hubungan antara jenis lantai rumah dengan kejadian tuberkulosis di Wilayah Puskesmas Bandaharjo dengan $\mathrm{P}$ value 0.37 (>0.05)

Penelitian yang dilakukan oleh Nugroho (2010) menunjukkan bahwa sebagian besar kasus TB sudah memiliki lantai rumah yang kedap air. Walaupun sudah memiliki jenis lantai yang kedap air tidak membuat kelembaban dalam ruangan menjadi lebih baik. Hal ini dikarenakan pencahayaan dan ventilasi yang kurang. Penelitian tersebut juga menunjukkan bahwa sebagian besar rumah dangan kelembaban kamar yang tinggi berada di kelurahan dengan persentase rumah tidak sehat yang cenderung tinggi pula. Hal tersebut menunjukkan bahwa jenis lantai bukan faktor utama sebagai penyebab kejadian TB Paru tetapi kondisi rumah tidak sehat dan lingkungan secara umum.

Berdasarkan faktor jenis dinding rumah dapat diketahui bahwa $57.5 \%$ telah memiliki jenis dinding yang memenuhi persyaratan (jenis dinding permanen) dan $42.5 \%$ responden memiliki jenis dinding yang tdak memenuhi persyaratan (jenis dinding semi permanen). Hasil analisis dengan chi square menunjukkan bahwa nilai $\mathrm{P}$ kurang dari nilai $\alpha 0,05$ yang artinya terdapat hubungan antara jenis dinding rumah dengan kejadian TB. Dinding berfungsi sebagai pelindung, baik dari gangguan hujan maupun angin serta melindungi dari pengaruh panas. Beberapa bahan pembuat dinding adalah dari kayu, bambu, pasangan batu bata atau batu dan lain sebagainya, tetapi dari beberapa bahan tersebut yang paling baik adalah pasangan batu bata atau tembok (permanen) yang tidak mudah terbakar dan kedap air sehingga mudah dibersihkan. Dinding ruang tidur, ruang keluarga harus dilengkapi dengan sarana ventilasi yang berfungsi untuk pengaturan udara, karena dinding dapat memberikan kontribusi terciptanya kelembaban dan temperatur yang memungkinkan suatu bibit penyakit akan mati atau berkembangbiak, seperti kuman Tuberculosis yang dapat bertahan pada kelembaban dan temperatur tertentu (Alamsyah and Muliawati, 2013).

Hasil pada penelitian ini menunjukkan bahwa terdapat hubungan antara jenis dinding dengan kejadian TB Paru. Penelitian yang dilakukan oleh Noor (2013) menunjukkan hasil yang serupa yaitu terdapat hubungan yang signifikan antara jenis dinding dengan kejadian TB paru. Dalam penelitian tersebut dapat diketahui bahwa orang yang tinggal pada rumah dengan jenis dinding yang tidak memenuhi syarat memiliki risiko 1.548 lebih besar dibanding dengan orang yang tinggal pada rumah dengan jenis dinding yang memenuhi persaratan. Penelitian lain yang dilakukan oleh Dewi (2016) menunjukkan hal yang sama yakni adanya hubungan antara jenis dinding dengan kejadian tuberkulosis. Menurut penelitian 
tersebut jenis dinding yang tidak memenuhi syarat meningkatkan risiko terjadinya TB Paru sebesar 3,7 kali dibandingkan dengan jenis dinding yang memenuhi syarat.

\section{KESIMPULAN}

Terdapat hubungan antara kepadatan hunian, ventilasi rumah dan jenis dinding rumah dengan dengan kejadian TB Paru serta tidak terdapat hubungan antara jenis lantai rumah dengan kejadian TB Paru.

\section{DAFTAR PUSTAKA}

Anggraeni, S. K., Raharjo, M., \& Nurjazulli. (2015). Hubungan Kualitas Lingkungan Fisik Rumah dan Perilaku Kesehatan Dengan Kejadian TB Paru Di Wilayah Kerja Puskesmas Gondanglegi Kecamatan Gondanglegi Kabupaten Malang. Jurnal Kesehatan Masyarakat, 3(1).

Dewi, E. F., Suhartono, \& Adi, M. S. (2016). Hubungan Faktor Lingkungan Rumah Dengan Kejadian Tb Paru di Kota Magelang. Jurnal Kesehatan Lingkungan, 4(2).

Hamidah, Kandou, G. D., \& Posangi, J. (2015). Hubungan Kualitas Lingkungan Fisik Rumah Dengan Puskesmas Perawatan Siko Kecamatan Ternate Utara. Journal E-Biomedik, 3(3).

Izzati, S., Basyar, M., \& Nazar, J. (2013). Artikel Penelitian Faktor Risiko yang Berhubungan dengan Kejadian Tuberkulosis Paru di Wilayah Kerja Puskesmas Andalas Tahun 2013, 4(1), 262-268.

Kemenkes RI.(1999). Kepmenkes RI No. 829 Tahun 1999 Tentang Persyaratan Kesehatan Perumahan. Jakarta: Kemenkes RI.

Lanus, I. N., Suyasa, I. N., \& Sujaya, I. N. (2012). Hubungan Antara Sanitasi Rumah Dengan Kejadian Tb Paru Di Kabupaten Bangli Tahun 2012. Jurnal Kesehatan Lingkungan, 4(2), 146151.
Manalu, H. S. (2010). Faktor-Faktor Yang Mempengaruhi Kejadian Tb Paru Dan Upaya Penanggulangannya. Jurnal Ekologi Kesehatan, 9(4), 1340-1346.

Noor, N. N., \& I Nyoman Sunarka. (2013). Analisa faktor risiko lingkungan terhadap kejadian tuberkulosis paru. Medula, 1(1), 7-13.

Notoatmodjo, S. (2011). Kesehatan Masyarakat Ilmu dan Seni. Jakarta: Rineka Cipta.

Oktavia, S., Mutahar, R., \& Destriatania, S. (2016). Analisis Faktor Risiko Kejadian Tb Paru Di Wilayah Kerja Puskesmas Kertapati Palembang. Jurnal Ilmu Kesehatan Masyarakat, 7(2), 124138.

P, R. S., A, M. I. A., \& Nahariani, P. (2013). Hubungan Tingkat Sosial Ekonomi Dengan Angka Kejadian Tb Paru Bta Positif Di Wilayah Kerja Puskesmas Peterongan Jombang Tahun 2012 (The Relation Of Economic Social With Occurerence Number Lungs Tuberculosis With Positive Bta In The District Of Puskesmas. Jurnal Metabolisme, 2(3), 31-38.

Pratama, B. Y., Budiarti, L. Y., \& Lestari, D. R. (2013). Karakteristik Lingkungan Fisik Rumah Dengan Kejadian Tb Paru. Jurnal Keperawatan Dan Kesehatan, 1(1), 16-23.

Setiadi, D., \& Adi, M. S. (2019). Pengetahuan, Praktik Pencegahan dan Kondisi Rumah pada Kontak Serumah dengan Penderita TB Paru di Kabupaten Demak. VisiKes, 18(1).

Wulandari, S. (2012). Hubungan Lingkungan Fisik Rumah Dengan Kejadian Tuberkulosis Paru. Unnes Journal of Public Health, 1(1), 3-6. 
36 Jurnal Ilmiah Sesebanua, Volume 5, Nomor 1, Maret 2021, hlm. 31-35 